\title{
Market Potential Tope Le'leng: Strategi Mengembangkan Industri Kecil Penenun Masyarakat Suku Kajang
}

\author{
Shinta Dewi Sugiharti Tikson', Nadya Septiani Sahas², Wahyu Nurul Ramadanti ${ }^{3}$, dan \\ Abdul Jalil Saleh ${ }^{4}$ \\ ${ }^{1}$ Fakultas Ekonomi dan Bisnis, Universitas Hasanuddin, Jl. Perintis Kemerdekaan Km.10, Makassar, \\ Indonesia \\ ${ }^{2}$ Departemen Manajemen, Universitas Hasanuddin, Makassar, Indonesia \\ shintatikson@fe.unhas.ac.id, nadyaseptianisahas.respect@gmail.com
}

\begin{abstract}
Abstrak: $\quad$ Pemerintah Desa Tanak toa menyebutkan $75 \%$ dari jumlah keluarga yang ada di Kajang memiliki satu industri tenun Tope Le’leng. Artinya di Suku Kajang terdapat 225 kepala keluarga yang memiliki keahlian membuat Tope Le'leng, khususnya wanita-wanita penenun Kajang. Guna meningkatkan atusiasme wanita penenun untuk terus berinovasi dan berkreasi dalam menghasilkan produk kreatif kain le'leng maka dibentuklah KALEA (Kajang Le'leng Ammatoa). KALEA adalah komunitas wanita penenun dan penjahit yang ada di Desa Tanah Toa, Kawasan Luar Tanah Adat, Kecamatan Kajang, Kabupaten Bulukumba, Provinsi Sulawesi Selatan. Seiring hadirnya KALEA di masyarakat Suku Kajang, maka inovasi dan kreasi kain tenun khas Kajang juga mengalami peningkatan. Hasil perhitungan market potential Tope Le'leng yaitu sebesar Rp. 900.000.000 (sembilan ratus juta rupiah). Diperkirakan dengan keunikan dan kualitas sarung hitam yang tinggi dan proses pemasaran yang kreatif serta produkyang bervariasi dapat meningkatkan pendapatan penenun secara signifikan. Hal inilah yang menjadi alasan mengapa industri ini memiliki potensi yang besar dalam memajukan perekonomian masyarakat Suku Kajang. Salah satu cara untuk menggali potensi tersebut adalah melalui pengembangan industri.
\end{abstract}

Kata Kunci: Market potential; Tope Le’leng; Suku Kajang; pemasaran; penenun

\section{PENDAHULUAN}

Indonesia memiliki seni warisan budaya berupa kain tenun yang secara turun temurun masih terjaga dan bernilai tinggi. Kain tenun tradisional Indonesia memiliki ciri khas yang unik dan beragam. Pembuatan kain tenun tersebar di beberapa daerah di Indonesia dan memiliki karakter yang berbeda-beda. Sulawesi Selatan memiliki berbagai macam kain tenun dan salah satunya adalah kain tenun khas Suku Kajang yang disebut Tope Le'leng.

Tidak seperti suku penghasil tenun lain yang sudah memperjualbelikan hasil tenun mereka, masyarakat Desa Tanah Toa, Kajang masih menenun untuk kebutuhan pribadi, atau untuk keperluan ritual adat. Selain itu, Tope Le'leng sulit di pasarkan oleh masyarakat Suku 
Kajang karena proses pembuatannya membutuhkan waktu yang lama dan sangat rumit (Sybli, 2011). Menenun satu sarung membutuhkan waktu tiga sampai empat bulan lamanya (Syaiful, 2017). Walaupun demikian, wanita Suku Kajang menenun setiap hari dan memiliki keinginan untuk menjual hasil tenun mereka seperti suku lainnya.

Pemasaran memiliki kaitan erat dengan aktivitas sehari-hari. Seperti halnya menenun merupakan keterampilan yang wajib dimiliki perempuan Suku Kajang karena menjadi syarat utama bagi perempuan Ammatoa Kajang agar bisa menikah. Aturan dan keterampilan menenun kain diwariskan secara turun temurun di Desa Tanah Toa (Rozak, 2019). Sehingga, tingkat keterampilan menenun wanita Kajang setelah menikah tidak diragukan lagi mengingat menenun telah menjadi kebiasaan yang memiliki nilai tinggi di mata masyarakat Suku Kajang.

Pemerintah Desa Tanah Toa menyebutkan bahwa 75\% dari jumlah keluarga yang ada di Kajang memiliki satu industri tenun Tope Le'leng. Hal ini menjadi peluang besar untuk melihat potensi pasar atas produk tenun yang mereka hasilkan. Konsep pemasaran pada dasarnya sederhana dan penting untuk dipahami juga diketahui oleh seluruh pelaku bisnis, termasuk industri kecil seperti penenun Tope Le'leng. Pemasaran merupakan kombinasi dari aktivitas-aktivitas yang saling berkaitan satu sama lain sehingga suatu usaha harus dapat mengetahui apa yang dibutuhkan oleh konsumen. Menurut Kotler dan Armstrong (2018) kebutuhan konsumen bisa diperoleh dengan melakukan pengambilan data marketing information dimana sebuah industri dapat menggunakan informasi tersebut untuk mengetahui potensi pasar dan kebutuhan konsumen.

Melihat minat dan kebutuhan konsumen yang beragam, suatu industri tradisional kain tenun seperti penenun kain le'leng harus terus berkreasi dan membuat produk inovasi berkualitas tinggi agar produk yang dihasilnya dapat dijual ke masyarakat luas dan bukan hanya untuk kebutuhan ritual adat semata. Seperti yang diikemukakan oleh McCarthy et al. (1994) proses produksi dan pemasaran merupakan dua elemen penting dalam sistem bisnis yang bertujuan untuk memberikan kepuasan konsumen atas barang dan/atau jasa yang dihasilkan. Seiring berjalannya waktu dan hadirnya Komunittas KALEA di masyarakat suku Kajang, inovasi dan kreasi kain tenun khas Kajang juga mengalami peningkatan. Akan tetapi, komunitas wanita penenun dan penjahit tersebut belum mengetahui potensi pasar dari produk yang mereka hasilkan. Oleh karena itu, hasil penelitian ini diharapkan dapat memberikan gambaran umum kepada penenun Suku Kajang mengenai potensi pasar hasil tenun mereka di masyarakat 
luas. Dengan demikian dapat membantu penenun Tope Le'leng memasarkan hasil tenunnya secara lebih luas dengan tujuan menciptakan kemandirian ekonomi masyarakat lokal.

\section{TINJAUAN PUSTAKA}

\subsection{Pengertian Pemasaran}

Tujuan utama pemasaran adalah melakukan identifikasi terhadap kebutuhan konsumen dan bagaimana cara agar dapat memenuhi kebutuhan tersebut. Penting untuk dipahami bahwa pemasaran tidak hanya diperuntukkan pada perusahaan besar semata namun kegiatan pemasaran juga penting untuk dilakukan pada usaha atau industry kecil seperti industtri tenun Tope Le'leng. Menurut McCarthy et al. (1994) setiap organisasi atau usaha perlu mempertimbangkan pasar dan bagaimana untuk memenuhi kebutuhan konsumen. Pemasaran merupakan sistem keseluruhan dari kegiatan usaha yang ditujukan untuk merencanakan, menentukan harga, mempromosikan dan mendistribusikan barang, jasa, ide kepada pasar sasaran agar tujuan organisasi tercapai.

Stanton (2007) menyatakan pemasaran adalah suatu sistem kegiatan bisnis yang dirancang untuk merencanakan, menentukan harga, promosi dan mendistribusikan barang atau jasa yang dapat memuaskan kebutuhan konsumen dan mencapai pasar sasaran serta tujuan perusahaan. Sedangkan menurut Kotler dan Keller (2016) pemasaran adalah suatu proses sosial menggunakan nama individu dan kelompok untuk mendapatkan apa yang mereka butuhkan dan inginkan dengan menciptakan dan mempertukarkan hasil produksi dan nilai kepada individu atau kelompok.

\subsection{Konsep Pemasaran}

Konsep dasar pemasaran terdiri dari tiga tahapan yaitu strategi dan analisis pemasaran; arah strategi and formulasi strategi; dan proses manajemen (Wilson dan Gilligan, 2009). Selanjutnya Kotler dan Keller (2016) menyatakan bahwa pemasaran adalah fungsi bisnis untuk mengidentifikasi kebutuhan-kebutuhan dan keinginan yang belum terpenuhi, menentukan dan mengukur besarnya potensi keuntungannya, menentukan pasar target yang paling dapat dilayani oleh organisasi, memutuskan berbagai produk, jasa, dan program yang paling tepat untuk melayani semua pasar yang sudah dipilih sebelumnya, mengajak setiap orang dalam organisasi untuk selalu berpikir dan melayani para pelanggan. 
Berdasarkan penjelasan diatas dapat dikatakan bahwa fungsi pemasaran yaitu mengkonversikan berbagai kebutuhan orang yang berubah-ubah menjadi peluang yang dapat memberikan keuntungkan. Hal ini sejalan dengan tujuan pemasaran yaitu untuk menciptakan nilai dengan cara menawarkan solusi-solusi yang unggul, menghemat usaha dan waktu pencarian yang dilakukan pembeli, serta usaha yang digunakan untuk bertransaksi, dan juga menyediakan standar kehidupan yang lebih tinggi bagi masyarakat.

Pemahaman tersebut sangat penting agar pemasar dapat merancang komunikasi yang sesuai dengan sasaran konsumen, sehingga konsumen bisa menerima produk atau jasa yang dipasarkan. Pemasar mengharapkan konsumen menilai produk atau jasa sebagai sesuatu yang cocok atau sesuai dengan kepribadiannya sehingga mereka menyukai, tertarik untuk membeli dan menggunakan produk dan jasa tersebut. Definisi-definisi pemasaran bersandar pada konsep inti yaitu kebutuhan (needs), keinginan (wants), dan permintaan (demand), serta requirement produk (barang, jasa, gagasan), nilai, biaya, dan kepuasan, pertukaran dan transaksi, hubungan dan jaringan, pasar, serta pemasar dan prospek (Wilson dan Gilligan, 2009).

Perusahaan yang telah menyadari bahwa pemasaran sangat penting bagi keberhasilan sebuah perusahaan perlu mengetahui dan mempunyai suatu falsafah tertentu yang disebut dengan konsep pemasaran. Kotler dan Keller (2016) berargumen bahwa konsep pemasaran merupakan kunci untuk mencapai tujuan organisasi yang ditetapkan, perusahaan tersebut harus menjadi lebih efektif dibandingkan dengan pesaing dalam menciptakan, menyerahkan, dan mengkomunikasikan nilai pelanggan kepada pasar sasaran yang terpilih. Konsep pemasaran menurut Kotler terdiri dari empat pilar yaitu:

\section{Pasar Sasaran}

Perusahaan akan berhasil bila secara cermat memilih pasar sasarannya dan mempersiapkan program-program pemasaran yang dirancang khusus untuk pasar tersebut.

\section{Kebutuhan Pelanggan}

Sebuah perusahaan dapat mendifinisikan pasar sasaran tetapi sering gagal untuk memahami kebutuhan pelanggan secara akurat. Memahami kebutuhan dan keinginan pelanggan tidak selalu sederhana. Beberapa pelanggan memiliki kebutuhan yang tidak sepenuhnya mereka sadari. Kita dapat membedakan diantara lima jenis kebutuhan: kebutuhan yang 
dinyatakan, kebutuhan riil, kebutuhan yang tidak dinyatakan, kebutuhan kesenangan dan kebutuhan rahasia.

\section{Pemasaran Terpadu}

Bila semua departemen diperusahaan bekerjasama untuk melayani kepentingan pelanggan, hasilnya adalah pemasaran terpadu. Pemasaran terpadu bisa terjadi pada dua level, Pertama, berbagai fungsi pemasaran (tenaga penjualan, periklanan, pelayanan pelanggan, manajemen produk, riset pemasaran) harus bekerja sama. Kedua, pemasaran harus dirangkul oleh departemen-departemen lain, mereka harus juga memikirkan pelanggan.

4 Kemampuan Menghasilkan Laba

Tujuan terakhir dari konsep pemasaran adalah membantu organisasi mencapai tujuan mereka yaitu menghasilkan laba atau keuntungan. Pada perusahaan swasta, tujuan utama adalah laba, pada organisasi publik dan nirlaba, tujuan utama adalah bertahan hidup dan menarik cukup dana guna melakukan pekerjaan yang bermanfaat. Perusahaan swasta seharusnya tidak bertujuan meraup laba saja melainkan mendapatkan laba sebagai akibat dari penciptaan nilai pelanggan yang unggul. Sebuah perusahaan menghasilkan uang karena memenuhi kebutuhan pelanggan lebih baik dibandingkan pesaingnya.

Banyak teori dan praktek tentang konsep pemasaran terpusat pada seni menarik pelanggan baru dari pada mempertahankan pelanggan yang sudah ada. Penekanannya lebih diarahkan pada penjualan dan bukan membangun hubungan pra-penjualan serta penjualan dan bukan pada perhatian terhadap pelanggan setelah penjualan. Pada dasarnya kepuasan dan ketidakpuasan pelanggan atas produk berpengaruh terhadap pembelian selanjutnya, jika pelanggan merasa puas bukan tidak mungkin mereka akan melakukan pembelian kembali sehingga akan membangun keputusan konsumen.

Secara definitif konsep pemasaran merupakan sebuah falsafah bisnis yang menyatakan bahwa pemasaran kebutuhan konsumen merupakan syarat ekonomi dan sosial bagi kelangsungan hidup perusahaan (Stanton, 2007). Kemudian Kotler dan Armstrong (2018) menyatakan bahwa untuk mencapai tujuan organisasi tergantung pada penentuan kebutuhan dan keinginan pasar sasaran, kepuasan pelanggan secara lebih efektif dibanding dengan yang dilakukan pesaing. 


\subsection{Market Potential}

Menurut Kotler dan Keller (2016) market potential adalah seperangkat konsumen dengan tingkat minat yang cukup dalam terhadap penawaran pasar. Namun, minat mereka tidak cukup untuk mendefinisikan pasar kecuali mereka juga memiliki penghasilan dan akses yang memadai terhadap produk yang ditawarkan oleh perusahaan. Penelitian ini akan menganalisis minat masyarakat terhadap penawaran pasar tenun Tope Le'leng sehingga penenun dapat melihat potensi pasar produk yang mereka hasilkan.

Untuk mengetahui secara jelas potensi pasar Tope Le'leng di masyarakat luas, maka penelitian ini akan melakukan analisis menggunakan perhitungan market potential. Kotler dan Keller (2016) menjelaskan market potential adalah penjualan maksimum yang tersedia untuk semua perusahaan dari sebuah industri selama periode tertentu di bawah tingkat upaya pemasaran industri tertentu dan kondisi lingkungan. Adapun hipotesis penelitian yakni: Tenun Tope Le'leng memiliki market potential (potensi pasar) yang besar di masyarakat luas.

Gambar 1. Kerangka Pemikiran

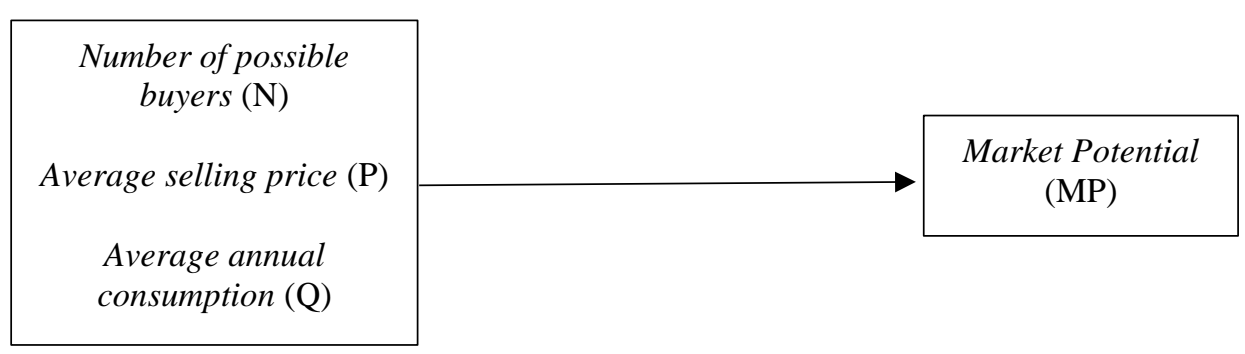




\section{METODE PENELITIAN}

Penelitian ini menggunakan metode penelitian kuantitatif. Metode penelitian kuantitatif adalah suatu cara yang digunakan untuk menjawab masalah penelitian yang berkaitan dengan data berupa angka dan program statistik (Wahidmurni, 2017). Cara umum untuk memperkirakan market potential adalah dengan mengalikan potensi tersebut dengan jumlah pembeli dan jumlah rata- rata setiap pembelian, kemudian dikalikan dengan harga (Kotler dan Keller, 2016). Untuk mengetahui market potential Tope Le'leng, maka akan menggunakan rumus:

$$
\begin{aligned}
& \text { MP }=\mathrm{N} \times \mathrm{P} \times \mathrm{Q} \\
& \text { Keterangan: } \\
& \mathrm{MP} \quad \text { : Market Potential } \\
& \mathrm{N} \quad \text { : Number of possible buyers } \\
& \mathrm{P} \quad \text { : Average selling price } \\
& \mathrm{Q} \quad \text { : Average annual consumption }
\end{aligned}
$$

\section{HASIL DAN DISKUSI}

Penelitian ini menggunakan data primer yakni data yang diperoleh melalui observasi atau pengamatan langsung, baik itu melalui observasi, kuesioner dan wawancara secara langsung sesuai dengan kebutuhan dalam penelitian ini. Selain itu, data sekunder juga digunakan dengan memperoleh data yang secara tidak langsung, yaitu data tersebut penulis peroleh dari jurnal dan buku-buku literatur yang memberikan informasi tentang hal-hal yang berkaitan dengan penelitian.

Jumlah penenun Tope Le'leng yang berada baik dalam kawasan adat maupun diluar kawasan adat. Selain itu, data juga menunjukkan dari 500 penenun terdapat 15 orang penenun yang telah begabung dengan Komunittas KALEA. KALEA adalah sebuah usaha social enterprise yang fokus memberdayakan Tope Le'leng dan menghimpun ibu-ibu penenun atau masyarakat desa Kajang yang belum diberdayakan untuk bekerja sebagai penenun milenial yang dapat menghasilkan produk berkualitas tinggi dengan macam kreasi 
yang selanjutnya langsung dijual ke seluruh pelosok Indonesia baik secara online maupun offline. Seperti yang diketahui bahwa salah satu permasalahan penenun Suku Kajang ada pada proses pemasaran karena kurangnya edukasi cara pemakaian alat elektronik seperti smartphone. Oleh karena itu Tope Le'leng hanya dipasarkan pada pasar-pasar tradisional. Dengan mengetahui potensi pasar Tope Le'leng maka nantinya pemasaran Tope Le'leng akan berbasis online dan target pasar yang lebih luas menjangkau ke seluruh Indonesia.

Tenun di Kajang bukan sekadar menciptakan lembaran-lembaran kain yang eksotis, tetapi juga cara yang senantiasa mengajarkan masyarakat berdampingan dengan alam. Tidak hanya itu, menenun bagi masyarakat Suku Kajang juga merupakan bagian dari mempertahankan dan melestarikan budaya adat Kajang. Dari hasil wawancara dengan ketua KALEA menyatakan bahwa penjualan produk Tope Le'leng masih didominasi oleh konsumen lokal dengan jumlah penjualan sebanyak 1.000 produk kain le'leng per tahun. Untuk penjualan secara nasional sebanyak 100 produk kain le'leng per tahun dan seacra internasional sebanyak 10 produk per tahun. Peminat Tope Le'leng di luar kawasan Suku Kajang cukup banyak, sehingga dapat dijadikan sebagai peluang pasar untuk para penenun dan Komunitas KALEA untuk memasarkan produk Tope Le'leng ke masyarakat yang lebih luas. Namun karena kurangnya pengetahuan pemasaran membuat ibu-ibu rumah tangga dan Komunitas KALEA memiliki keterbatasan dalam memasarkan hasil tenun mereka secara lebih luas.

\section{Perhitungan Market Potential Tope Le'leng}

Untuk mengetahui secara jelas potensi pasar Tope Le'leng di masyarakat luas, maka penelitian ini akan melakukan analisis menggunakan perhitungan market potential. Kotler dan Keller (2016) menjelaskan market potential adalah penjualan maksimum yang tersedia untuk semua perusahaan dari sebuah industri selama periode tertentu di bawah tingkat upaya pemasaran industri tertentu dan kondisi lingkungan. Cara umum untuk memperkirakan market potential adalah dengan mengalikan potensi tersebut dengan jumlah pembeli dan jumlah rata- rata setiap pembelian, kemudian dikalikan dengan harga (Kotler dan Keller, 2016).

Tabel 1. Market Potential Tope Le'leng

\begin{tabular}{|l|c|}
\hline \multicolumn{1}{|c|}{ Deskripsi } & Jumlah \\
\hline Penjualan Tope Leleng per tahun & 1.000 \\
\hline $\begin{array}{l}\text { Jumlah rata-rata produk yang dibeli oleh konsumen per satu } \\
\text { kali pembelian }\end{array}$ & 3 \\
\hline Harga rata-rata Tope Leleng & Rp 300.000 \\
\hline
\end{tabular}

Sumber: Data primer, 2020 (Wawancara) 
Industri tenun sarung hitam adalah suatu usaha pengolahan benang biasa yang diwarnai dengan warna hitam alami dari tumbuhan alam. Benang tersebut diolah dengan cara ditenun secara tradisional hingga menghasilkan sebuah sarung atau kain hitam. Dalam proses pembuatannya satu buah Tope Le'leng membutuhkan 7 sampai 12 hari untuk diselesaikan. Sarung hitam biasanya dijual dengan harga Rp.500.000 sampai Rp.1.000.000 per buahnya. Sehingga suatu usaha industri yang dikelola oleh 1 orang produsen per 7 hari dapat menerima pendapatan sebesar Rp.500.000 sampai Rp.1.000.000. Artinya industri ini perharinya dapat menerima pendapatan kotor sebesar Rp.72.000 sampai Rp.143.000. Dari hasil wawancara dengan beberapa orang warga yang memiliki industri tenun Tope Le'leng, menyatakan bahwa pendapatan kotor sebesar Rp.72.000 sampai Rp.143.000 per harinya belum bisa menunjang kebutuhan dalam satu keluarga.

Berdasarkan hasil observasi dan wawancara tersebut, peneliti memiliki tujuan untuk membantu melihat market potential (MP) Tope Le'leng. Hasil perhitungan market potential Tope Le'leng yaitu MP $=(1.000 \times$ Rp 300.000 x 3) sehingga market potential Tope Le'leng sebesar Rp 900.000.000 (Sembilan ratus juta ribu rupiah). Diperkirakan dengan keunikan dan kualitas sarung hitam tinggi dan proses pemasaran yang kreatif serta produk yang bervariasi dapat meningkatkan pendapatan penenun secara signifikan. Hal inilah yang menjadi alasan mengapa industri ini memiliki potensi yang besar dalam memajukan perekonomian masyarakat Suku Kajang. Salah satu cara untuk menggali potensi tersebut adalah melalui pengembangan industri.

\section{KESIMPULAN}

Seiring hadirnya KALEA di masyarakat Suku Kajang, maka inovasi dan kreasi kain tenun khas Kajang juga mengalami peningkatan. Hal ini bisa dijadikan peluang untuk melihat potensi pasar yang lebih luas. Dengan mengidentifikasi potensi pasar akan memudahkan penenun dan Komunitas KALEA dalam memasarkan produk kain le'leng yang dihasilkan ke pasar yang lebih luas. Diharapkan hasil penelitian ini dapat membantu penenun Tope Le'leng dalam melihat potensi pasar produk kain le'leng sehingga dapat meningkatkan produktifitas dan penghasilan masyarakat Suku Kajang juga meningkatkan eksistensi kain tenun khas Kajang di Indonesia agar dapat bersaing dengan hasil tenun khas Indonesia lainnya. 
Adapun kekurangan atau limatasi dari penelitian ini: (a) waktu penelitian yang sangat singkat dan dalam kondisi pandemi Covid-19 maka pengambilan data primer tidak bisa maksimal, (b) untuk penelitian selanjutnya baiknya melakukan survey pada konsumen lokal, nasional dan internasional yang pernah membeli produk kain le'leng sehingga dapat mengetahui kekurangan dan kelebihan produk dari persepsi konsumen.

\section{ACKNOWLEDMENTS}

Terima kasih kepada Lembaga Penelitian dan Pengabdian kepada Masyarakat (LP2M) Universitas Hasanuddin yang telah mendukung penelitian ini dengan memberikan pendanaan dalam bentuk hibah internal universitas. Selain itu, terima kasih kepada seluruh anggota tim peneliti yang telah bekerja sama sehingga penelitian ini dapat dilaksanakan dan diselesaikan.

\section{DAFTAR PUSTAKA}

Kotler, P. dan Keller, K. L. (2016). A Framework for marketing management (6 ${ }^{\text {th }}$ ed.). London: Pearson Education.

Kotler, P. dan Armstrong, G. (2018). Principles of marketing (1 $7^{\text {th }}$ ed.). London: Pearson Education.

McCarthy, E. J. et al. (1994). Basic marketing: a managerial approach (1 ${ }^{\text {st }}$ ed.). $\quad$ Sydney: Irwin.

Rozak, A. (2019). Arti selembar kain tenun perempuan Ammatoa Kajang. Diakses dari https://www.gatra.com/detail/news/440903/lifestyle/arti-selembar-kain-tenunperempuan-ammatoa-kajang.

Stanton, W. J. (2007). Fundamentals of marketing (International student edition). Minnesota: McGraw-Hill.

Syaiful. 2017. Tenun Tope Le'leng Kajang, jadi sasaran penelitian siswi kelas IX MTSN 1 Bulukumba. Diakses dari https://sulsel.kemenag.go.id/artikel-950-tenuntope-leleng-kajang-jadi-sasaran-penelitian-siswi-kelas-ix-mtsn-1-bulukumba. 
Sybli, N. (2011). Mengenal tenun Suku Kajang. Diakses dari https://m.inilah.com/news/detail/1811594 /mengenal-tenun-suka-kajang.

Sugiyono. (2001). Statistika untuk penelitian. Bandung: Alfabeta.

Wahidmurni. (2017). Pemaparan metode penelitian kuantitatif. Diakses dari http://repository.uin-malang.ac.id/1985/2/1985.pdf.

Wilson, R. M. S. dan Gilligan, C. (2009). Strategic marketing planning (2 ${ }^{\text {nd }}$ ed. ). Oxford: Elsevier. 